\title{
New Linyphiidae spiders associated with playas in the Southern High Plains (Llano Estacado) of Texas (Arachnida: Araneae)
}

\author{
JAMES C. COKENDOLPHER ${ }^{1}$, SHANNON M. TORRENCE ${ }^{2}$, LOREN M. SMITH ${ }^{3}$ \& NADINE \\ DUPÉRRÉ ${ }^{4}$ \\ ${ }^{1}$ Invertebrate Collection, Natural Science Research Laboratory, Museum of Texas Tech University, Lubbock, Texas 79409, U.S.A. e- \\ mail: james.cokendolpher@ttu.edu (corresponding author) \\ ${ }^{2}$ Wildlife and Fisheries Management Institute, Mail Stop 2125, Texas Tech University, Lubbock, Texas 79409, U.S.A. Current address: \\ Coastal Conservation Program, Texas Parks and Wildlife Department, 1502 FM 517 East, Dickinson, Texas 77539, U.S.A. e-mail: \\ Shannon.Torrence@tpwd.state.tx.us \\ ${ }^{3}$ Wildlife and Fisheries Management Institute, Mail Stop 2125, Texas Tech University, Lubbock, Texas 79409 U.S.A. Current address: \\ Department of Zoology, Oklahoma State University, Stillwater, Oklahoma 74078, U.S.A. e-mail: loren.smith@okstate.edu \\ ${ }^{4} 12$ Chemin Saxby sud, Shefford, Québec, J2M 1S2, Canada.e-mail: dupere.nadine@videotron.ca
}

\begin{abstract}
Three species [Ceratinella playa new species, Erigone denticulata Chamberlin \& Ivie, Mermessus denticulatus (Banks)] in the spider family Linyphiidae were associated with emergent vegetation in playa wetlands in the Southern High Plains of Texas. Playa wetlands are being rapidly degraded in the Great Plains of the U.S.A. We describe and illustrate the new species Ceratinella playa from a male and female from Briscoe County, Texas. Erigone denticulata is redescribed and illustrated from males and females from Texas. New distributional records are provided for E. denticulata from the U.S.A.: Colorado, Idaho, Nevada, Oregon, Texas, Utah, and Wyoming. All of these except those from Wyoming are new state records. A new county record of Mermessus denticulatus is reported from Texas.
\end{abstract}

\section{RESUMEN}

Tres especies [Ceratinella playa nueva especie, Erigone denticulata Chamberlin \& Ivie y Mermessus denticulatus (Banks)] de la familia Linyphiidae fueron asociadas a la vegetación emergente en cuerpos de aguas temporales "playas" de humedales en las Grandes Planicies del sur de Tejas. Los humedales están siendo degradados rápidamente en las Planicies de los E.E.U.U. Se describe e ilustra macho y hembra de la nueva especie Ceratinella playa del condado Briscoe, Tejas. Machos y hembras de Erigone denticulata de Tejas son redescritos e ilustrados. Nuevos datos distribucionales son reportados para E. denticulata para los estados de Colorado, Idaho, Nevada, Oregón, Tejas, Utah y Wyoming. Todos, excepto los de Wyoming, son nuevas citas para estos Estados. Mermessus denticulatus se cita por primera vez para Tejas.

Key words: Ceratinella, Ceraticelus, Erigone, Mermessus, wetland, new records, new species, playa, taxonomy, U.S.A.

\section{INTRODUCTION}

The family Linyphiidae currently has 578 genera and > 4,300 described species (Platnick 2007). Member species are found throughout the world, except for mainland Antarctica. They occupy almost all terrestrial habitats, even ice and snow, but are most diverse and abundant in mesic environments or wetlands (Ubick et al. 2005). Because ballooning is a common means of moving great distances by some members of this family, some species have global distributions. Others are much more limited in their range and occupy restricted environments such as caves and isolated islands (Buckle et al. 2001; JCC, ND pers. obs.). 

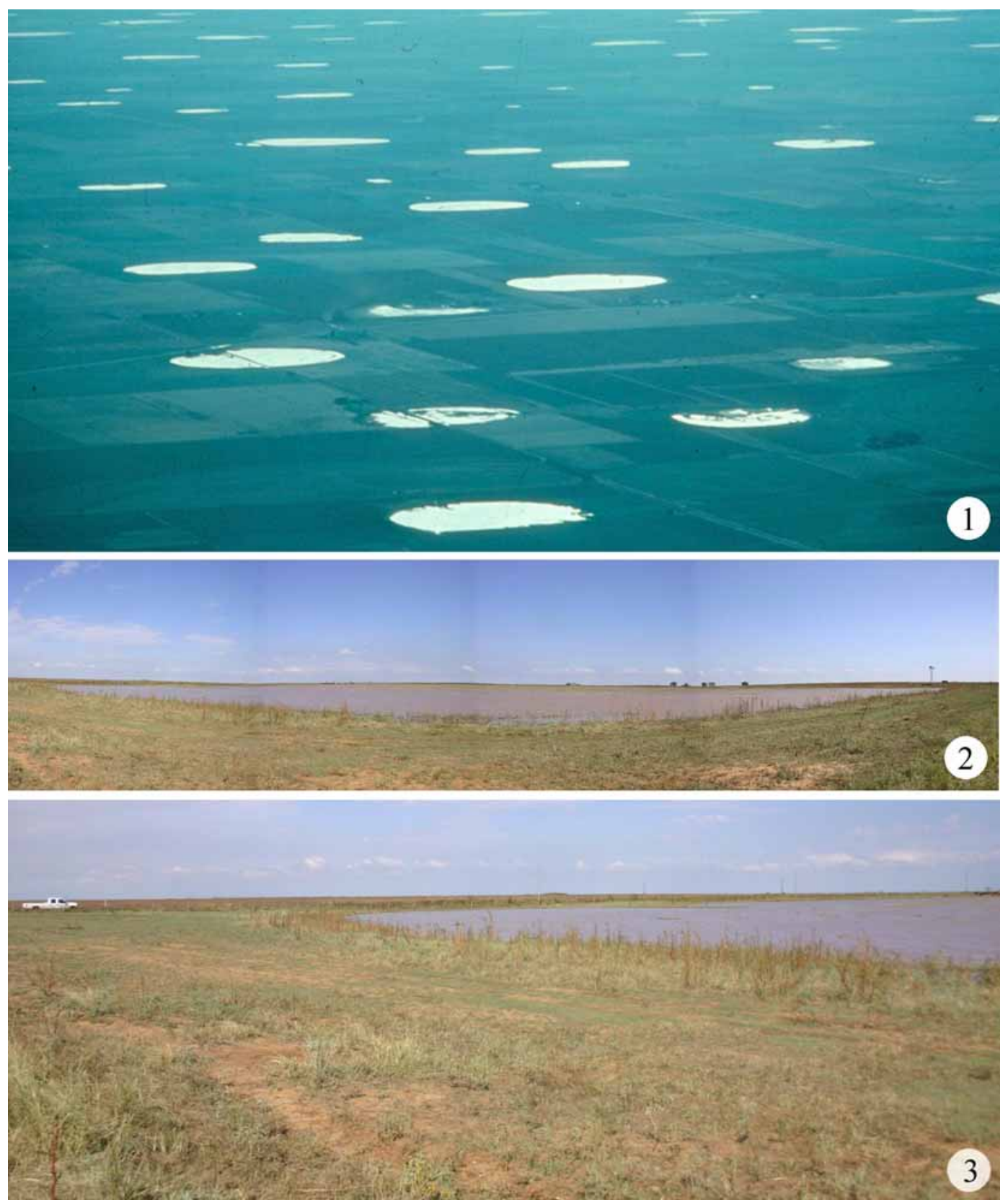

FIGURES 1-3. 1, Aerial view of some playa lakes on the flat landscape of the Southern High Plains (Llano Estacado) of Texas (photograph by Wyman Meinzer, courtesy of the U.S. Fish and Wildlife Service). 2, Panoramic view (stitched from four photographs) from the dirt road west of Playa BR13 looking east on the High Plains of Texas. Note the very flat landscape and lack of larger vegetation [photographs by Jo-Szu (Ross) Tsai] during August 2004. 3, Closeup of the left corner of Fig. 2 showing the short vegetation (mostly grasses); pick-up truck not cropped to indicate size of playa [photograph by Jo-Szu (Ross) Tsai].

This paper describes investigations in the playas in the south-central U.S.A. Although the Spanish word "playa" means beach, the word is used on the Southern High Plains (Llano Estacado) of Texas and New Mexico, U.S.A., for shallow depressional wetland features. The approximately 25,000 to 30,000 playas are the most numerous hydrogemorphic features in the Southern High Plains (Fig. 1), but they only occupy $2 \%$ of the landscape (Haukos \& Smith 1994). Therefore, they serve as key sites of biodiversity in this otherwise flat, semi-arid landscape (Bolen et al. 1989). Playas are recharge wetlands each existing within its individual watershed (Smith 2003). As depressional recharge wetlands, they only receive water from precipitation and runoff from the immediate area. They only lose water to groundwater recharge and evapotranspiration. Playas are ephemeral and their hydroperiods are extremely variable, varying from days to over a year (Smith 2003). 
In the spring and summer, playa ecosystems change when rain from thunderstorms inundates dry playas. These playas, along with those containing water from previous rainfall, become habitat for enormous numbers of aquatic invertebrates (Anderson \& Smith 2000, Hall et al. 2004). Some of the insects mature and emerge from the waters to feed the many terrestrial predators.

Wetlands are being rapidly degraded throughout the Great Plains, U.S.A. (Smith 2003). The greatest immediate threat to playas is sedimentation resulting from erosion of cultivated soils surrounding the wetlands (Luo et al. 1997). These eroded upland soils have buried hydric soils, which subsequently alters hydroperiods and dependent floral and faunal communities (Smith \& Haukos 2002).

Although the presence of the family Linyphiidae is documented in playas (Smith 2003), this is the first study to identify members of this family to genus and species. Prior to this study, the two species described here were taxonomically uncertain and only listed to family. Additionally, another described species from a more recently revised genus (Mermessus denticulatus) is also reported. We describe a new species of Ceratinella and provide a modern redescription of Erigone denticulata Chamberlin \& Ivie.

\section{MATERIALS AND METHODS}

\section{Collection Methods}

Spiders described here were collected as part of a food web study (Torrence 2007) focusing on aquatic invertebrates and larval amphibians. We took one sweep, $5 \mathrm{~m}$ long, with a net (dimensions: $33 \times 51 \mathrm{~cm}$, pore size $500 \mu \mathrm{m}$ at each of four locations within 12 playas every other day. The bottom of the net remained on the floor of the playa, and at water depths $<33 \mathrm{~cm}$ the net breached the surface of the water. The net pushed down emergent vegetation, and consequently we collected spiders and other invertebrates occupying the canopy of emergent vegetation. The number of terrestrial invertebrates inhabiting the canopy comprised about $0.6 \%$ of the total abundance of invertebrates collected (Torrence 2007). Sampling started on 28 May 2005 and ended on 12 July 2005.

\section{Laboratory Methods}

Samples were preserved in the field in $70 \%$ ethanol, transferred to the laboratory for sorting and enumeration, and then were transferred to fresh $70 \%$ ethanol. For illustration, specimens were examined in $70 \%$ ethanol with a SMZ-U Nikon dissection microscope. A Nikon Coolpix 950 digital camera attached to that microscope was used to take a photograph of the carapace, pedipalp and all other structures for illustration. The digital photo was then used to trace structure proportions, and the illustration was detailed and shaded by referring back to the structure under the microscope. Female genitalia were excised using a sharp entomological needle and transferred to $85 \%$ lactic acid to clear non-chitinous tissues. A temporary lactic acid mount was used to examine the genitalia with an Olympus BX40 compound microscope, and was photographed and illustrated as explained above. The genitalia and the rest of the spider was then rinsed and placed in microvials filled with $70 \%$ ethanol. All measurements were made using an ocular micrometer in the eyepiece of a Nikon/ SL3-D compound microscope. Photographs presented here as Figs 4-7 were made with a Nikon Coolpix E8800 mounted on the same Nikon/SL3-D microscope with stacks of images being combined with AutoMontage and PhotoShop. Specimens or detached parts were examined for measurements and descriptions while immersed in $\mathrm{K}-\mathrm{Y} ®$ brand jelly. After > hour, this material dries and becomes too rigid to manipulate the specimens into desired positions. The viscosity of the jelly was decreased by the addition of $100 \%$ glycerol. Descriptions are based on specimens that were preserved in ethanol. The anatomical terminology follows that presented in the Spiders of North America (Ubick et al. 2005). Calculation for the location of metatarsal trichobothria (Tm) follows Denis (1949). Acronyms for collections are the American Museum of Natural History, New York (AMNH); Collection Paquin-Dupérré, Montréal, Québec, Canada (CPAD); Invertebrate Collection, Museum of Texas Tech University (TTU-Z). 


\section{TAXONOMY}

\section{Family Linyphiidae Blackwall}

\section{Ceratinella Emerton}

Comments.-Members of Ceratinella and Ceraticelus (= Idionella Banks, following Buckle et al. 2001) are very similar to each other in that these species have a dorsal shield or scutum on the abdomen of at least the males.

There are 29 recorded species of Ceratinella globally. Platnick (2007) listed 28 species in Ceratinella ranging across the Holarctic region, and a species from New South Wales. Ubick et al. (2005) recognized 14 from North America. A total of 41 species of Ceraticelus Simon is recorded in North America (Ubick et al. 2005) and Platnick (2007) catalogued an additional three species from Russia and the northern West Indies.

Previously members of Ceratinella were considered to have the cephalic area unmodified in males, Ceraticelus species have this area unmodified, or with one or two lobes. The Ceratinella cheliceral fang sometimes is shortened and has a double curve, promargin with 0 denticles, retromargin with $0-2$ denticles; whereas the Ceraticelus fang is straight, not curved nor shortened. The Ceratinella cheliceral promargin has 4 denticles, retromargin with 2 denticles. TmIV is present in Ceratinella, absent in Ceraticelus. The Ceraticelus formosus group (= Idionella, in part): cephalic region unmodified, dorsal scutum of abdomen extends over anterior of abdomen to contact pedicel; epigastric scutum extends up only to pedicel. Apophysis of pedipalpal tibia extends sideways from mid-tibia, then abruptly right-angled (anteriorly) near tip.

As can be seen by comparing the description of our new species with the character list above, our species is more like Ceraticelus in the cheliceral dentition (having numerous denticles) and TmIV absence, but that group is confused and polyphyletic as is Idionella (see Buckle et al. 2001). We have chosen to include our species in Ceratinella because the pedipalpal morphology appears to match more closely other members of that genus. The pedipalpal embolus is coiled basally; distally with final loop, no break or prong in distal half, distal loop not recurved upon itself at an acute angle (more gently rounded); radical tailpiece elongated and spiraled throughout.

\section{Ceratinella playa Cokendolpher, Torrence, Smith \& Dupérré, new species}

(Figs 4-6, 8, 10-16)

Type material-_HOLOTYPE male: U.S.A.: Texas: Briscoe County: Playa BR13, 15 June 2005, S.M. Torrence, L.M. Smith, N34³2'12.336" W101ํ1'37.212" (TTU-Z 29,902). ALLOTYPE female: U.S.A.: Texas: Briscoe County: Playa Br59, N34²4'40.896" W101¹7'16.54800", 22 June 2005, S.M. Torrence, L.M. Smith, (TTU-Z 29,903).

Diagnosis.-The unmodified cephalic region, coiled pedipalpal embolus, distally arising tibial apophysis, cheliceral dentition pattern-promargin 5-6, retromargin 2, and cheliceral fang not double-curved separate this species from all Ceratinella, Ceraticelus, and Idionella.

Description.-Male (Holotype, Fig. 8): Total length: $1.54 \mathrm{~mm}$; carapace length: $0.68 \mathrm{~mm}$; carapace width: $0.51 \mathrm{~mm}$. Carapace smooth to slightly rugose, cephalic region unmodified, without pits, brownishorange infuscate with dark brown (Fig. 4). Sternum wide brownish-orange infuscate, smooth, coxae of legs IV widely separated, posterior of sternum broadly truncate, its flat end about $1 / 3$ sternum maximum width (Fig. 5). Chelicerae uniformly colored as carapace. Cheliceral stridulatory file not evident with dissection microscope (visible as striae at 200X). Cheliceral fang straight, not shortened, unmodified; promargin with 1 large and 5 smaller denticles (Fig. 4), retromargin with 2-3 smaller denticles (Fig. 5) (small denticles on both margins equal in size). Abdomen unpatterned, scutum $0.75 \mathrm{~mm}$ long, remainder of abdomen $0.12 \mathrm{~mm}$ long. Scutum amber to orange with numerous large granules (anterior granules pointed and hooked) tipped with 
long setae (Fig. 6), dorsal scutum extends over anterior of abdomen to near the pedicel. Epigastric scutum extends up only to pedicel. Abdomen pale tan, sclerotized and amber colored around spinnerets ventrally. Legs light amber; tibia II-IV with one dorsal macroseta; TmI 0.49, TmIV absent. Pedipalpal tibia with a thick, stout, curved apophysis (Figs 10-12); tibial apophysis with a fine field of minute denticles on mesal side of tip (visible at 400X); embolus thin, coiled basally, not separate from ductule, no break or prong in distal half (Fig. 10,11 ), distally with final loop, distal loop not recurved upon itself at an acute angle (more gently rounded); radical tailpiece elongated and spiraled throughout (Fig. 10); protegulum white to light gray colored, contrasting with darkened sclerotized parts; other details of the pedipalp are as in Figs 10, 11.

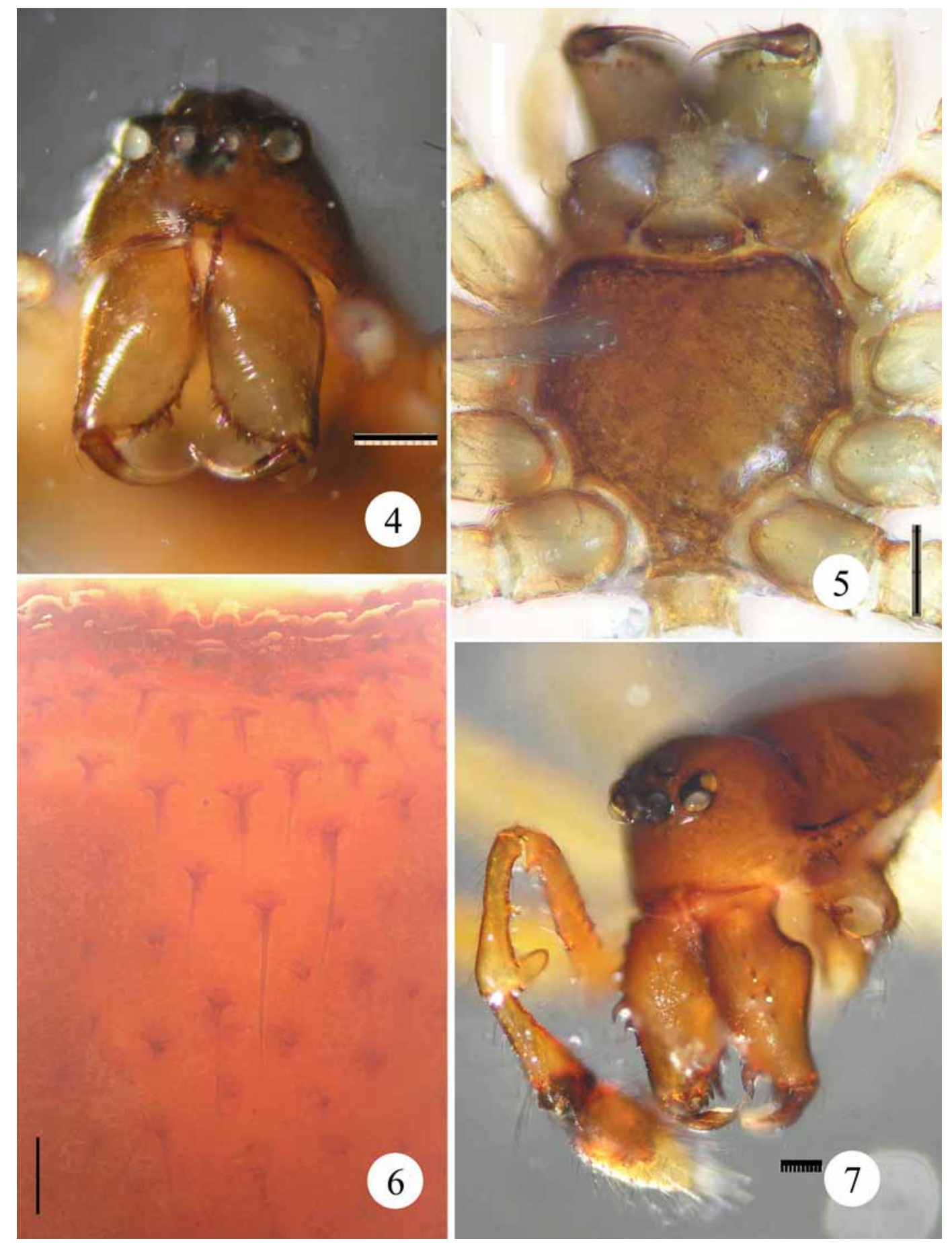

FIGURES 4-7. Males: 4-6, Ceratinella playa new species, 4, anterior view of carapace and chelicera; 5, ventral view of pedicel to chelicera; $\mathbf{6}$, closeup view of anterior edge of dorsal scutum of abdomen; 7, Erigone denticulata Chamberlin \& Ivie cephalothorax and appendages anteriolateral view; 7, Scale bars $=0.1 \mathrm{~mm}$, except Fig. $6=0.05 \mathrm{~mm}$. 


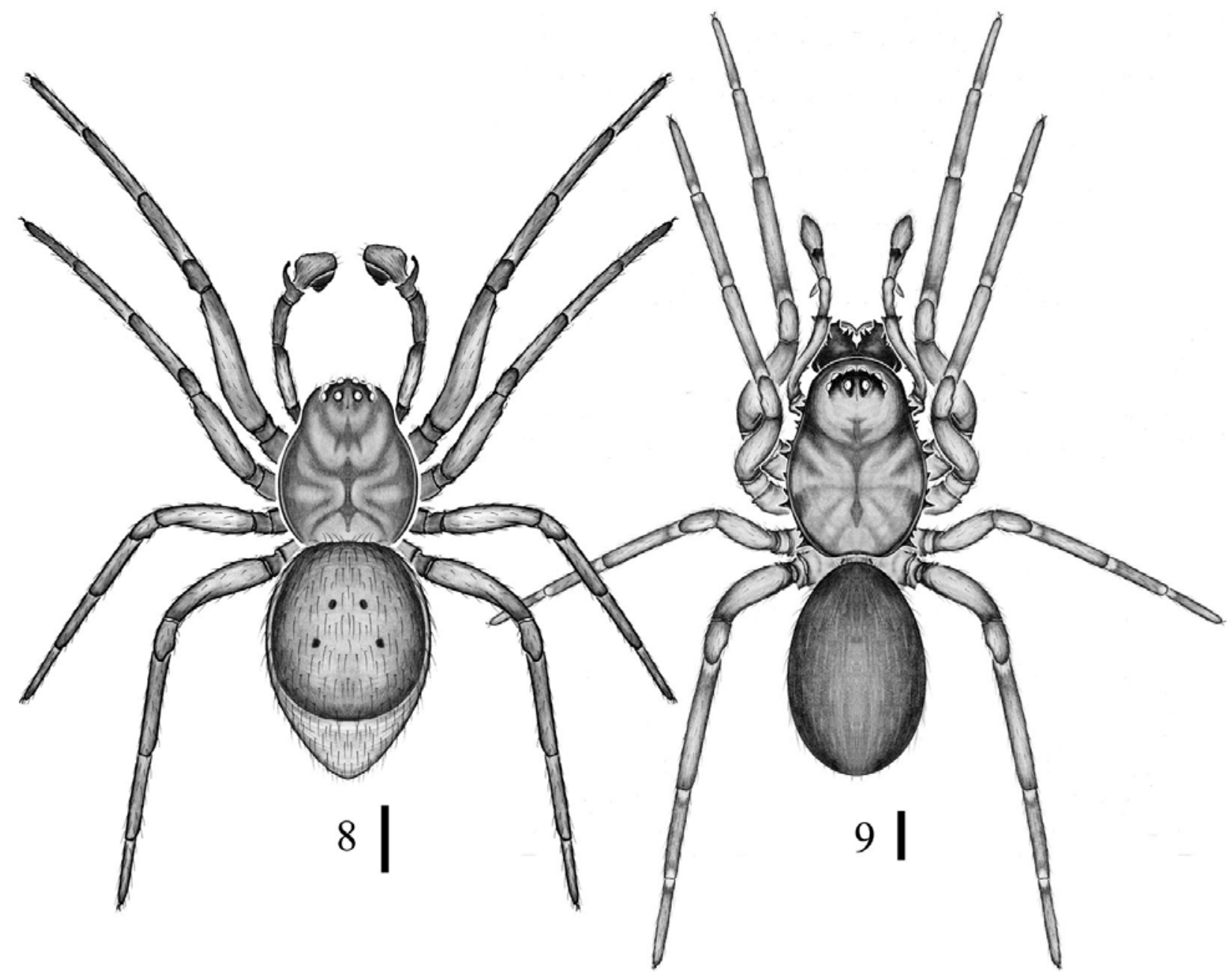

FIGURES 8-9. Habitus of males: 8, Holotype of Ceratinella playa new species; 9, Erigone denticulata Chamberlin \& Ivie. Scale bars $=0.25 \mathrm{~mm}$.

Female: Total length: $1.54 \mathrm{~mm}$, carapace length: $0.75 \mathrm{~mm}$, carapace width: $0.46 \mathrm{~mm}$. Carapace colored like legs, chelicera slightly darker. Carapace setal pattern with 4 erect setae along midline. Sternum colored as carapace but more infuscate with dark brown. Cheliceral promargin with 2 large and 3 small denticles and retromargin with 2 denticles. Cheliceral stridulatory file not visible with dissection microscope (visible as striae at 200X). Abdomen length $0.79 \mathrm{~mm}$, seta-crowned tubercles much less pronounced than in male, uniformly colored (no pattern nor maculations) dark brown, densely covered with semi-erect setae; without scutum. Legs light yellow to amber; tibia II-IV with one dorsal macroseta each, tibia I with 2 smaller macrosetae; TmI 0.44 , TmIV absent. Posterior portion of the epigynal plate sclerotized as in Fig. 13. Spermathecae only faintly visible through the cuticle and not extending beyond the epigynal plate (Figs 14-16). Spermathecae oval, fertilization ducts strongly curved inwards, copulatory ducts short and curled/looped (Figs 14-16).

Distribution.- Thus far only collected within about an $11 \mathrm{~km}$ radius of Silverton, Briscoe County, Texas, U.S.A.

Habitat. - The canopy of emergent aquatic vegetation within playa wetlands. The type locality had primarily grasses when it was photographed (Figs 2,3), a year before the collections were made.

Etymology.-The specific name is a noun in apposition to the genus, Ceratinella; from the western U.S.A. English "playa" meaning shallow depressional wetlands in the Southern High Plains, U.S.A. (not the Spanish "playa" = beach). The name refers to discovering this species in playas. 


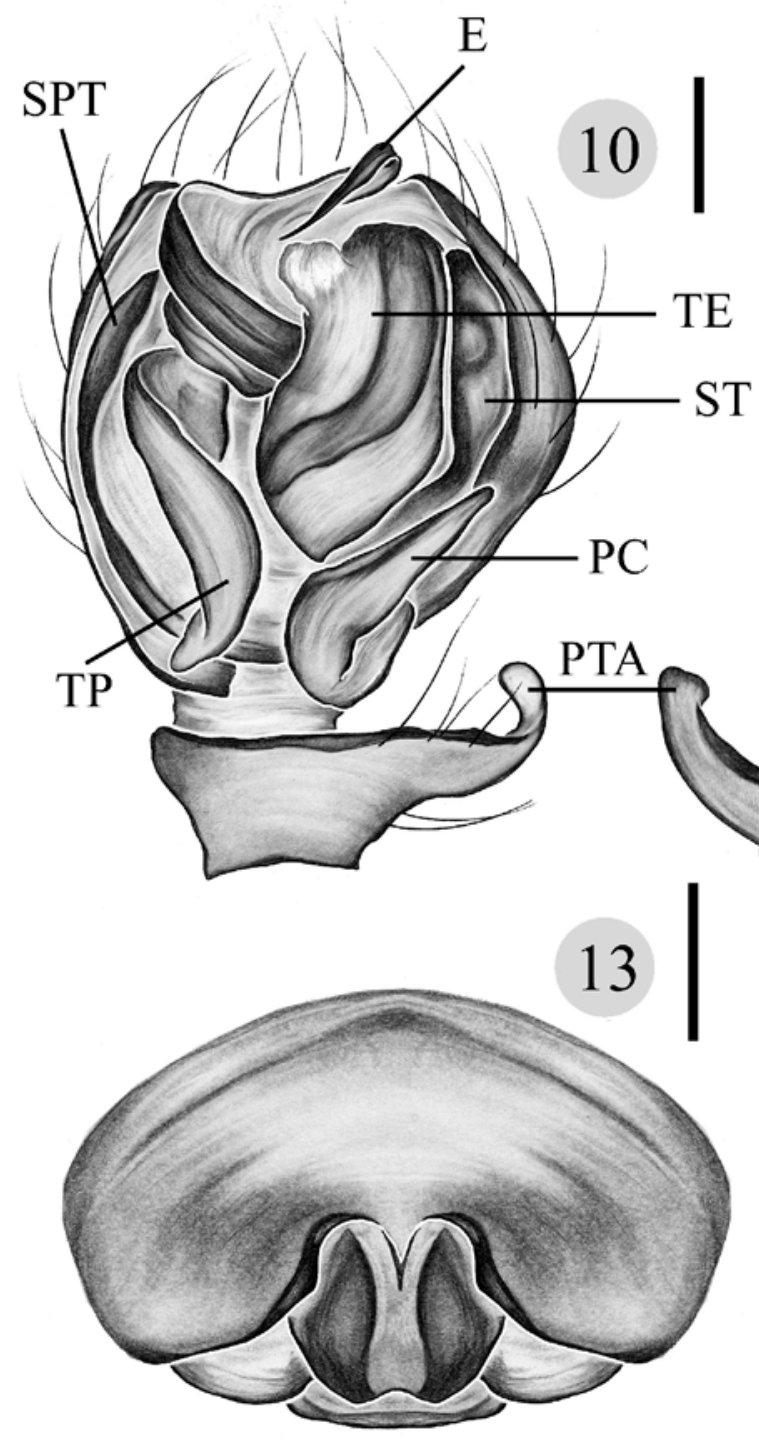

\section{$\mathrm{ST}$}
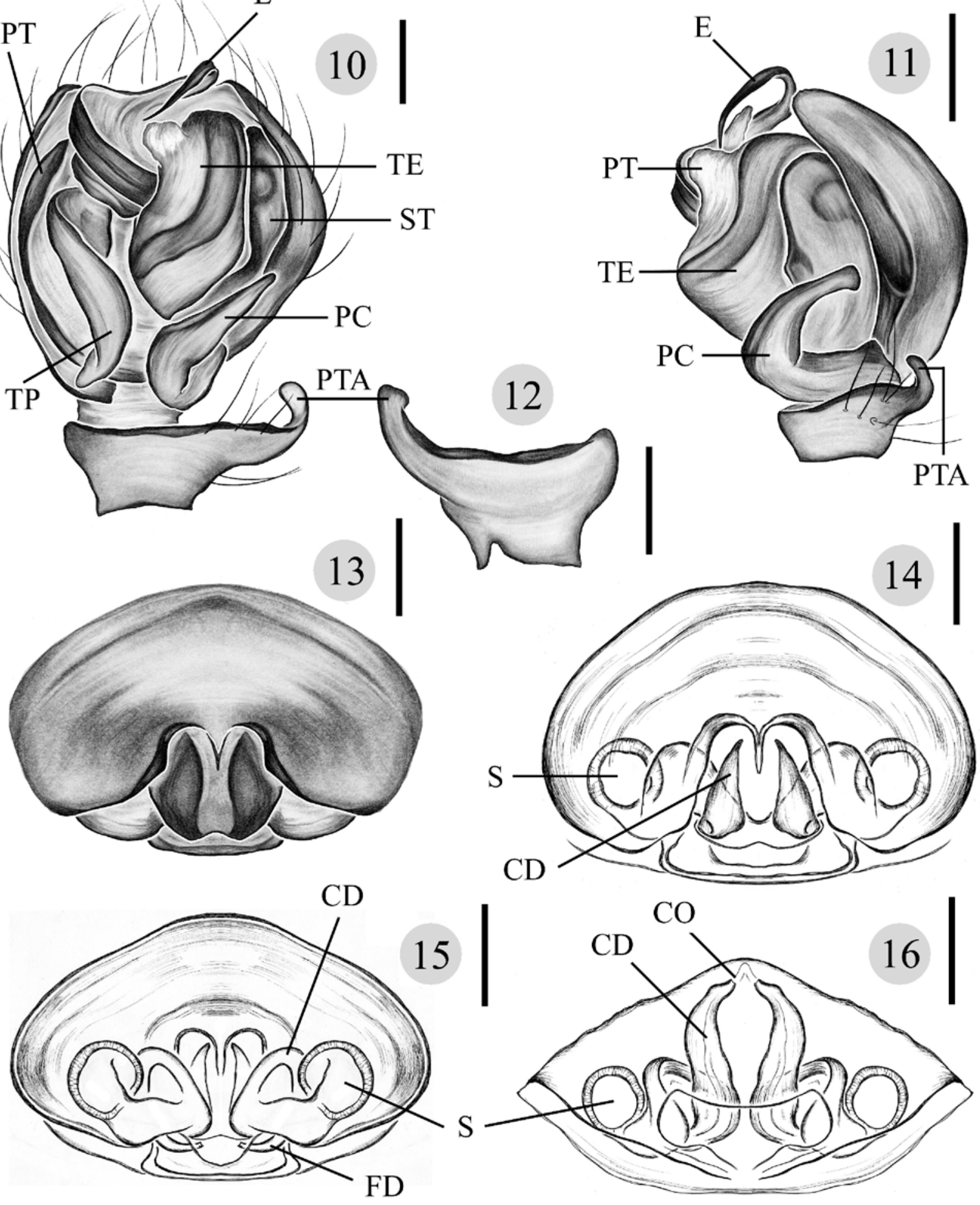

FIGURES 10-16. Male holotype and female allotype Ceratinella playa new species: 10, distal end of pedipalpus of male, ventral view; 11, distal end of pedipalpus of male, retrolateral view; 12, pedipalpal tibia of male, dorsal view; 13, epigynum, ventral view; 14, spermathecae, ventral view; 15, spermathecae, dorsal view; 16, spermathecae, posterior view. Abbreviations used: $\mathbf{C O}$ copulatory opening, CD copulatory ducts, $\mathbf{E}$ embolus, FD fertilization ducts, PC paracymbium, PT protegulum, PTA pedipalpal tibia apophysis, S spermatheca, SPT suprategulum, ST subtegulum, TE tegulum, TP radical tailpiece. Terminology follows Hormiga (2000). Scale bars $=0.05 \mathrm{~mm}$. 


\section{Mermessus denticulatus (Banks)}

Tmeticus denticulatus Banks 1898, 243, pl. 14, fig. 29; see Platnick (2007) for further literature records. Centromerus denticulatus: Roewer 1942, 532.

Erigone eschatologica Crosby in Chamberlin 1924, 643, figs 85-88.

Eperigone eschatologica: Crosby \& Bishop 1928, 51, figs 113-116; Millidge 1987, 37, figs 132-136; Platnick (2007). Mermessus denticulatus (Banks): Miller 2007, 132, fig. 92(G, H).

Material Examined.-U.S.A.: Texas: Floyd County: Mitchell East Playa, N3358’ W10129', 20 Sept. 1994, Jim Anderson (TTU-Z 13,377).

Comments.-Although this spider was not collected in the present study in Briscoe and Swisher Counties, a male voucher from Anderson's (1997) study of playas in Floyd County (the county immediately south of Briscoe County) revealed this species. This specimen was collected in the emergent vegetation in a playa. The new county record for this spider fills a blank in its recorded range. When Millidge (1987) revised the genus and updated the species description and distribution, he listed samples from Potter, Knox, and Lipscomb Counties from northwestern Texas, but did not provide specifics on the localities. Platnick (2007) listed the range of this species as U.S.A. to Colombia, introduced to Europe. The only natural history information provided by Millidge (1987) was that adults were collected from throughout the year and the only habitat mentioned was "crevices in a clay bank in Georgia."

\section{Erigone denticulata Chamberlin \& Ivie}

(Figs 7, 9, 17-23)

Erigone denticulata Chamberlin \& Ivie 1939, 57, fig. 2; Levi \& Levi 1951, 220; Levi \& Levi 1955, 36; Buckle et al. 2001, 116; Platnick 2007.

Type material.-U.S.A.: Utah: Summit County: Mirror Lake, Uintah Mountains, N4042' W110 49', 22 Sept. 1932, W. Ivie, male holotype (not examined). Mirror Lake, N4043' W11053', 28 July 1936, Wilton Ivie, 3 males labeled by Ivie as paratypes (AMNH, examined).

Material examined.-U.S.A.: Colorado: Grand County: Hot Sulphur Springs, N406' W106 9', 24 Aug. 1935, W. Ivie, 1 male, 1 female (AMNH). Idaho: Payette County: N.E. Fruitland, N44ำ $1^{\prime}$ W116 $55^{\circ}$, 1 July 1938, W. Ivie, 4 males, 1 females (AMNH). Nevada: Elko County: Ruby Valley, N40 $15^{\prime}$ W $115^{\circ} 25^{\prime}$, Sept. 1937, R.V. Chamberlin, 4 males, 3 females (AMNH). Oregon: Malheur County: $8 \mathrm{~km}$ south of Adrian, N4340' W117, 19 Sept. 1943, W. Ivie, 3 males, 1 female (AMNH). Texas: Lubbock County, Lubbock, N33 32'2" W101 ${ }^{\circ} 53^{\prime 2} 23^{\prime \prime}$, Sept. 2006, J.C. Cokendolpher, in wet greenhouse next to man-made pond, 1 female (TTU-Z 29,680); same locality \& collector, on waterfall of man-made pond, 11 June 2007 (AMNH); Briscoe County: Playa Br5, N34²9'4.91999" W101 ${ }^{\circ}{ }^{\prime} 54.359^{\prime \prime}, 17$ June 2005, S.M. Torrence, L.M. Smith, 1 female (AMNH); Playa Br13, N34³2'12.336" W101¹7'37.212", 15 June 2005, S.M. Torrence, L.M. Smith, 1 female (CPAD). Playa Br13, N34³2'12.336" W101¹7'37.212", 17 June 2005, S.M. Torrence, L.M. Smith, 1 female (TTU-Z 29,683). Playa Br19, N34²8'19.01999" W101'15'32.616', 22 June 2005, S.M. Torrence, L.M. Smith, 1 male, 1 female (TTU-Z 29,681 and 29,679); 26 June 2005, S.M. Torrence, L.M. Smith, 1 female (TTU-Z 29,682). Swisher County: Playa S6, N34³2'37.644" W101³4'14.808", 21 June 2005, S.M. Torrence, L.M. Smith, 1 male (CPAD). Utah: Summit County: Mirror Lake, Uintah Mountains, N40 $43^{\prime}$ W110 53', 22 Sept. 1932, W. Ivie, 3 females (AMNH). Wyoming: Albany County: southeast of Laramie, N41 $10^{\circ} 5^{\prime \prime}$ W $105^{\circ} 21^{\prime} 0 "$ ", July 1961, W.D. Fronk, 1 male, 1 female (AMNH).

Diagnosis.-Male with marginal rows of large and smaller sharp pointed denticles on the sides of carapace (Figs 7, 9, 17); pedipalpal patella with large and long distal apophysis, with single small denticle at about midpoint (Figs 7, 18); pedipalpal tibia straight across distodorsal end, not notched or otherwise modified in center (Fig. 16). Female epyginum with only slightly rounded lobes posteriorly (Fig. 21); spermathecae elongate and compressed in center (Figs 22, 23). 
Description (Briscoe County, specimens illustrated)._Male (Fig. 9): Total length: $2.18 \mathrm{~mm}$; carapace length: $1.05 \mathrm{~mm}$; carapace width (excluding denticles): $0.77 \mathrm{~mm}$; carapace with lateral row of denticles with a small ridge above row (Fig. 7; similar to Hormiga 2000, fig. 86a). Sternum darker brown. Chelicera depressed basally on retrolateral marginal face, with 8 large, distally curved denticles on anteriolateral margins and 1012 denticles scattered over promargin basally, also few short thick macrosetae basal to stridulatory file, promargin with 1 mega denticle and 1 large denticle, retromargin with 3 denticles plus 1 smaller distal denticle; cheliceral stridulatory file as large striae on posteriolateral surface (visible with dissection microscope). Cheliceral fang thickened on basal half and with a brush of very fine denticles centrally. Abdomen $1.13 \mathrm{~mm}$ long, uniformly colored, no patterns. Legs, tibia I-IV with one dorsal macroseta; metatarsus I with dorsal trichobothrium, TmI 0.43, TmIV 0.52. Pedipalpal femur curved mesally, then dorsally, recurved at distal end (Figs 9, 18), mesal side with longitudinal row of denticles; patella with a thick, stout, apophysis (Figs 7, 18); tibia straight across distodorsal end, not notched or otherwise modified in center, mesal side (about 2/3 from basal end) with raised area tipped with small spur-like point (Fig. 18, 19); embolus thick, straight, pointed at tip (Figs 18, 19); other details of pedipalp as in Fig. 19.

Female: Total length: $2.65 \mathrm{~mm}$, carapace length: $1.05 \mathrm{~mm}$, carapace width: $0.75 \mathrm{~mm}$; carapace coloration as in male, pattern 3 erect setae along midline. Carapace and chelicerae dark amber to yellowish-brown, sternum darker brown; carapace elevated in anterior third; posteriolateral margins of carapace with noticeable small granules to minute denticles; without ridge laterally as in male. Chelicera slightly enlarged basally, with 6-8 denticles in a row on anteriolateral margin; promargin of cheliceral fang furrow with 2 larger and 3 smaller denticles (distal most minute), retromargin with 3 denticles (one distal smaller denticle on each chelicera); stridulatory file not visible with dissection microscope (present as striae on posteriolateral margin at 200X). Abdomen unpatterned, darker brown to gray brown, darker than carapace; length $1.60 \mathrm{~mm}$, densely covered with semi-erect setae. Legs light yellow to amber, tibia I-IV each with one dorsal macroseta; metatarsus I with dorsal trichobothrium, TmI 0.57, TmIV absent. Posterior portion of the epigynal plate sclerotized (Fig. 21). Spermathecae only slightly visible through the cuticle and not extending much beyond the epigynal plate (Figs 22,23). Spermathecae oval and oriented obliquely, fertilization ducts only slightly curved, copulatory ducts long and curved (Fig. 23).

Distribution.-Known from Colorado, Idaho, Montana, Nevada, Oregon, Texas, Utah, and Wyoming in the central and northwestern U.S.A.

Habitat.-In the present study we only found specimens in the canopy of emergent aquatic vegetation within playa wetlands and next to a man-made pond in a wet greenhouse. Levi \& Levi (1951) stated that this species was also collected at Moran (Grand Teton National Park, Teton County, Wyoming) from an aspen grove.

Remarks.-In the original description of this species, Chamberlin \& Ivie (1939) stated that E. denticulata was related to Erigone ostiaria Crosby \& Bishop, but differed by being larger in size and by the details of the pedipalpus. By comparing Crosby \& Bishop (1928) figs 149-151 to our Figs 13-15 the pedipalpal differences are apparent. Also, E. ostiaria is thus far only known from Washington State, U.S.A.

In having a mid-position denticle on the pedipalpal patella, this species could be confused with Erigone dentosa O. Pickard-Cambridge (from British Columbia south to Guatemala); however, the denticle on E. dentosa is noticeably larger and distinctly curved distally (Crosby \& Bishop 1928, fig. 42). These are not very closely related species, but the denticle is used in the diagnoses presented by Crosby \& Bishop (1928).

Crawford (in Buckle et al. 2001 p. 116) stated that this species is probably the same as Erigone aletris Crosby \& Bishop. These two species appear similar, especially in the details of the pedipalp in ventral view, but we are able to separate the two taxa. As illustrated by Paquin \& Dupérré (2003, figs 958-963) E. aletris differs from E. denticulata in features of the male and female genitalia. Erigone aletris occurs throughout much of the northern Holarctic region and appears to be absent from the plains of the central U.S.A. 

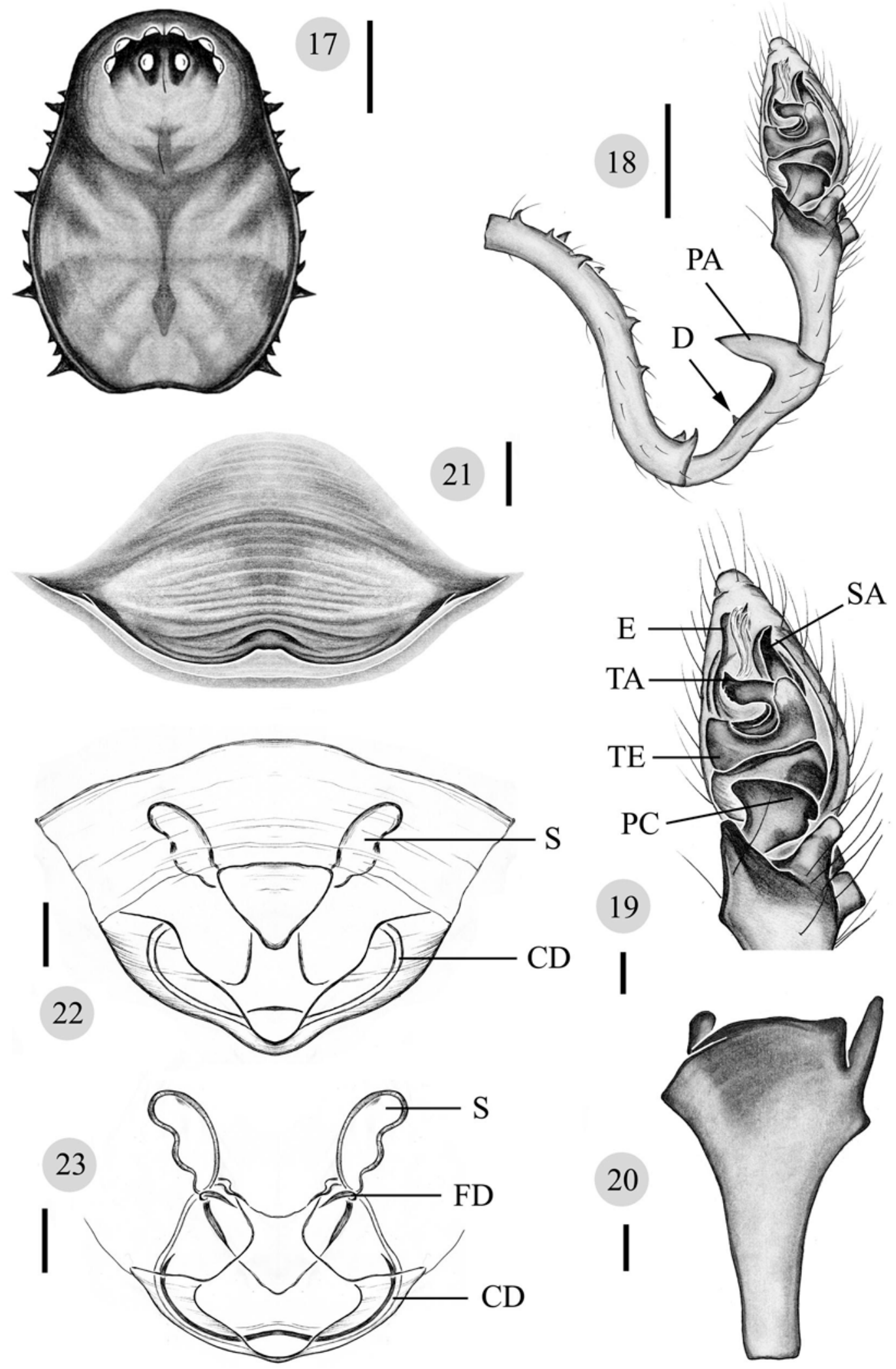

FIGURES 17-23. Male and female Erigone denticulata Chamberlin \& Ivie 1939 from playas in Briscoe County, Texas. 17, carapace of male; $\mathbf{1 8}$, pedipalpus of male, ventral view; 19, enlarged view of pedipalpal tibia of male, ventral view; 20, pedipalpal tibia of male, dorsal view; 21, epigynum, ventral view; 22, spermathecae, posterior view; 23, spermathecae, dorsal view. Abbreviations used: CD copulatory ducts, D patellar denticle, E embolus, FD fertilization ducts, PA patellar apophysis, PC paracymbium, SA suprategular apophysis, S spermatheca, TA tegular apophysis, TE tegulum, Terminology follows Hormiga (2000). Scale bars for figures $17,18=0.25 \mathrm{~mm}$, all other figures $=0.05 \mathrm{~mm}$. 


\section{DISCUSSION}

Our study confirms what most spider taxonomists have determined through extensive investigations, genera within the Linyphiidae require serious taxonomic revision. Similarily, the taxonomic bounds of Ceratinella and Ceraticelus are unclear and require investigation.

Although C. playa and E. denticulata appear in only a few of the playa collections, their apparent rarity is most likely due to under collection (Smith 2003). Most likely, C. playa and E. denticulata have a wide distribution in playas, if not prairie wetlands in general, because linyphiids are highly mobile. These small spiders travel in the air on strands of silk (Weyman et al. 2002). Establishing the geographic range of these species would require extensive sampling. Inadvertently discovering a new species highlights the importance of identifying unknown specimens. Discovering a new species in playas has conservation importance because playas are not protected under any state or federal policy and have not received significant conservation by state or federal agencies. Playas face many threats, of which loss of playa volume is the greatest (Luo et al. 1997). Sedimentation can also alter vegetation structure (Smith \& Haukos 2002), the habitat in which we found these spiders. Finding a new species and new occurrences of species within these wetlands highlights the need for conservation of geographically isolated wetlands not protected under the Clean Water Act of the U.S.A.

\section{ACKNOWLEDGEMENTS}

This project was funded by the National Science Foundation Grant DMS-0201105. LMS was funded by the Caesar Kleberg Foundation for Wildlife Conservation. The following ranchers/farmers are thanked for access to their lands: Tom Burson, Max Weaver, Zane Mayfield, Jerry and Amanda Miller, John Nix, and Ken Wood. The aerial photograph was provided by photographer Wyman Meinzer of Benjamin, Texas (courtesy of the U.S. Fish and Wildlife Service). The photographs of the type locality of the new species were made by Jo-Szu (Ross) Tsai (Department of Natural Resources Management, TTU). We acknowledge and thank Dr. Norman I. Platnick and Lou Sorkin for their help and guidance during our (JCC, ND) stay at the American Museum of Natural History. We also thank Donald J. Buckle (Saskatoon, Saskatchewan) for assistance in trying to define the generic limits of Ceraticelus and Ceratinella. His comments were instructive as was his review of the manuscript. Tamara Enríquez (NSRL, TTU) is thanked for her help with the Resumen. An unidentified reviewer, Gustavo Hormiga, and Nikolaj Scharff provided useful comments on the manuscript which are appreciated.

\section{REFERENCES}

Anderson, J.T. (1997) Invertebrate communities in vegetated playa wetlands. PhD dissertation. Texas Tech University, Lubbock, Texas, U.S.A.

Anderson, J.T. \& Smith, L.M. (2000) Invertebrate response to moist-soil management of playa wetlands. Ecological Applications, 10, 550-558.

Banks, N. (1898) Arachnida from Baja California and other parts of Mexico. Proceedings of the California Academy of Sciences, Series 3, 1, 205-308.

Bolen, E.G., Smith, L.M. \& Schramm, Jr., H.L. (1989) Playa lakes: prairie wetlands of the Southern High Plains. BioScience, 39, 615-623.

Buckle, D.J., Carroll, D., Crawford, R.L. \& Roth, V.D. (2001) Linyphiidae and Pimoidae of America north of Mexico: Checklist, synonymy, and literature. In: Paquin, P. \& Buckle D.J. (Eds.), Contributions à la connaissance des araignées (Araneae) d'Amérique du Nord. Fabreries, Supplément 10, 89-191.

Chamberlin, R.V. (1924) The spider fauna of the shores and islands of the Gulf of California. Proceedings of the California Academy of Sciences, 12, 561-694, figs 1-140.

Chamberlin, R.V. \& Ivie, W. (1939) Studies on North American spiders of the family Micryphantidae. Verhandlungen, 
VII. Internationaler Kongreß für Entomologie, Berlin, 15.-20. August 1938, 1, pp. 56-73 + 6 plates.

Crosby, C.R. \& Bishop, S.R. (1928) Revision of the spider genera Erigone, Eperigone and Catabrithorax (Erigoneae). New York State Museum Bulletin, 278, 3-97.

Denis, J. (1949) Notes sur les érigonides. XVI. Essai sur la détermination des femelles d'Erigonides. Bulletin de la Société d'Historie Naturelle de Toulouse, 83(3-4),129-158.

Hall, D.L., Willig, M.R., Moorhead, D.L., Sites, R.W., Fish, E.B. \& Mollhagen, T.R. (2004) Aquatic macroinvertebrate diversity in playa wetlands: the role of landscape and island biogeographic characteristics. Wetlands, 24, 77-91.

Haukos, D.A. \& Smith, L.M. (1994) The importance of playa wetlands to biodiversity of the Southern High Plains. Landscape and Urban Planning, 28, 83-98.

Hormiga, G. (2000) Higher level phylogenetics of erigonine spiders (Araneae, Linyphiidae, Erigoninae). Smithsonian Contribution in Zoology, No. 609, 1-160.

Levi, H.W. \& Levi, L.R. (1951) Report on a collection of spiders and harvestmen from Wyoming and neighboring states. Zoologica, New York, 36(4), 219-237.

Levi, L.R. \& Levi, H.W. (1955) Spiders and harvestmen from Waterton and Glacier National Parks. The Canadian FieldNaturalist, 69(2), 32-40.

Luo, H.R., Smith, L.M., Allen, B.L. \& Haukos, D.A. (1997) Effects of sedimentation on playa wetland volume. Ecological Applications, 7, 247-252.

Miller, J.A. (2007) Review of erigonine spider genera in the Neotropics (Araneae: Linyphiidae, Erigoninae). Zoological Journal of the Linnean Society, 149(Suppl. 1), 1-263.

Millidge, A.F. (1987) The erigonine spiders of North America. Part 8. The genus Eperigone Crosby and Bishop (Araneae, Linyphiidae). American Museum Novitates, No. 2885, 1-75.

Paquin, P. \& Dupérré, N. (2003) Guide d'identification des araignées (Araneae) du Québec. Fabreries, Supplément 11, 1-251.

Platnick, N.I. (2007) The world spider catalog, version 7.5. American Museum of Natural History. Available from: http://research.amnh.org/entomology/spiders/catalog/index.html (accessed 25 April 2007).

Roewer, C.F. (1942) Katalog der Araneae von 1758 bis 1940. Vol. 1. Bremen, Natura.

Smith, L.M. (2003) Playas of the Great Plains. University of Texas Press, Austin. 275 pp.

Smith, L.M. \& Haukos, D.A. (2002) Floral diversity in relation to playa wetland area and watershed disturbance. Conservation Biology, 16, 964-974.

Torrence, S. (2007) Landuse and hydroperiod influences on amphibian community structure and the role of larval amphibians in the playa food web. PhD dissertation, Texas Tech University, Lubbock, Texas, U.S.A. (http:// etd.lib.ttu.edu/theses/available/etd-06122007-083804/). (accessed 4 July 2007).

Ubick, D., Paquin, P., Cushing, P.E. \& Roth, V. (eds) (2005) Spiders of North America. American Arachnological Society, 377 pp.

Weyman, G.S., Sunderland, K.D. \& Jepson, P.C. (2002) A review of the evolution and mechanisms of ballooning by spiders inhabiting arable farmland. Ethology, Ecology \& Evolution, 14, 307-326. 